\title{
Value for Money Audit: A Veritable Tool for Expenditure Management
}

\author{
Nwosu M. Eze ${ }^{1} \&$ Mshelia M. Ibrahim ${ }^{2}$ \\ ${ }^{1}$ Manager, Internal Audit, National Institute for Legislative Studies, National Assembly, Abuja, Nigeria \\ ${ }^{2}$ Deputy Director, Finance \& Accounts, National Institute for Legislative Studies, National Assembly, Abuja, \\ Nigeria \\ Correspondence: Nwosu M. Eze, Manager, Internal Audit, National Institute for Legislative Studies, National \\ Assembly, Abuja, Nigeria. E-mail: mail4eze@yahoo.co.uk
}

Received: May 27, 2015

Accepted: June 18, 2015

Online Published: July 16, 2015

doi:10.5430/ijfr.v6n3p150

URL: http://dx.doi.org/10.5430/ijfr.v6n3p150

\begin{abstract}
As a constitutional creation, it is the statutory responsibility of public sector organizations at federal, state and local government levels to embrace the concepts of value for money audit and integrate it in their organizations. However, determining how economical, efficient and the extent to which the related programmes are effective in meeting their objectives is still a subject of debate in most jurisdictions. Triangulating existing knowledge regarding the basic processes, while stating the ideas in practical and useable form, this paper examines the importance of value for money audit as a veritable tool for expenditure management and evaluates its crucial objectives and essential features. Using the desktop analytical approach, result shows that lack of value for money audit processes affects the smooth running and growth of an organization. The paper recommends for proper value for money audit in organisations and the independence of Internal Audit for the purposes of value for money audit functions.
\end{abstract}

Keywords: value for money audit, expenditure management, public sector organisation

\section{Introduction}

Value for money audit, according to Okwoli (2004:80) is "a systematic evaluation of the methodologies employed in the execution of programmes, projects, and activities with the objectives of confirming whether the stated objectives of the programmes, projects, and activities were actually achieved and at what cost". According to him, this method of audit has evolved over time and been found to be the best approach to confirming whether managers of resources are applying best practices in the use and application of resources.

He maintains that the best practices in this respect will be the extent to which the managers apply economically and efficiently the resources made available and how the expected results are being achieved. In effect, therefore, while the need to achieve stated results is of primary importance, the curtailment of waste and extravagance makes the results more realistic.

Oshisami (1992) Value for Money Audit determines whether the entity is acquiring, managing or utilizing its resources (staff, buildings, spaces, materials, etc) in an economic and efficient manner and the causes of any inefficiencies or uneconomical practices.

Oshisami (1992) went further to state that it involves an inquiry into whether in carrying out its responsibilities, the organization gives adequate consideration to optimal acquisition, procedures and practices, safe keeping of its assets, money and minimum expenditure of effort.

Value for money audit has been found to be particularly useful in public sector where measurement of results achieved by public sector organizations is more subjective than in the private sector. In the private sector, measurement of the success of an enterprise is a function of the profit of such an enterprise. Its continuous existence depends entirely on the ability of the enterprises to make profit without which it will fold up. Whereas the private sector enterprises endeavour to make profit in order to continue to remain in business. This particular urge is not very prevalent in public sector. Public sector enterprises are set up specifically to address various problems, some social, while some are economic. However, profit motive is not usually the main objective of setting up such bodies. Even though many of such enterprises are not strictly set up as profit-making organizations, it is expected that they should not contribute an undue burden to the Government. 
The managers in the civil service are usually provided with resources in the form of men, materials, money for the purpose of achieving stated objectives. How far these objectives are achieved depends on how these resources are utilized. Public service is a trust. It is therefore highly obligatory for any one, entrusted with such responsibility to exercise utmost prudence in the utilization of given resources and to ensure that the expected results are achieved.

\section{Objective of the Study}

This paper explores the ingredients and essential features of value for money audit as a veritable tool for expenditure management. While having an overview of the essential characteristics of value for money audit as being necessary and worth discussing. Value for money audit relates to the extent to which funds are expended economically and efficiently and the extent to which the related programmes are effective in meeting their objectives.

The term value for money as a desirable characteristic of the conduct of public business has only recently come into vogue. Value for money audit practice promotes a public service that is more responsible to public needs and is more accountable. In the opinion of Ene, (2000) value for money, in contemporary usage, summarizes the separate but inter-related values of efficiency and effectiveness. He clarifies that taken together, these values include the traditional values of prudence, due diligence, regularity, probity, integrity and equity. He expands those values as follows:

- $\quad$ Economy refers to the terms and conditions under which the Government acquires financial, human and physical resources in appropriate quality and quantity at the lowest cost.

- $\quad$ Efficiency refers to the relationship between goods or services and resources used to produce them. An efficient operation produces the maximum output for any given set of resources inputs or it has minimum inputs for any given quantity and quality of services provided.

- $\quad$ Effectiveness concerns the extent to which a programme achieves its goals and related effects. For example, to increase the income level in a particular area, a programme might be devised to create jobs. The jobs created would be programme output. This contributes to the desired programme effect of a higher income level, which can be measured to assess programme effectiveness. Of course, the effectiveness of programme is not always easily evaluated. Also, management procedures for measuring and reporting effectiveness will differ between programmes.

It has been opined by Ene, (2000) that the value for money aspects of public sector auditing are important steps towards assuring taxpayers concerning the accountability of Government to elected representatives and public officials for the receipt and spending of public money. He posits that in the light of this assertion external auditors concerned with assessing value for money issues ask the following questions respecting the 3 Es.

- $\quad$ Economy: Are we getting the right inputs at the least cost (getting a good deal)? Economy is essentially a resource acquisition concept with a least cost notion and is concerned with the acquisition of resources of appropriate quality and quantity at the lowest reasonable cost (buying resources at the right time at the favourable price, in the right quality and quantity). Economy means getting the right amount at the right time in the right place, at the right cost. Lack of economy in acquiring resources could result in a higher than necessary cost of products or services, of appropriate quality, quantity or timeliness.

- $\quad$ Efficiency: Are we getting the most output from our inputs (getting a lot of efforts)? Efficiency is essentially a resource-usage concept, also with a least-cost notion, is concerned with the maximization of minimal cost or the usage of minimum-input resources (as evidenced by high productivity, in- time performance). This refers to the relationship between the quantity and quality of goods and services produced (output) and the cost of resources used to produce them at a required service level to achieve programme results. An efficient operation either produces the maximum quantity of output of a given resource input, or uses minimum input to produce a given quantity and quality of output.

- $\quad$ Effectiveness: Are the inputs getting the results we want (doing the right things) Effectiveness has been defined as an ends-orientated concept that measures the degree to which predetermined goals and objectives for particular activity or programme are achieved (the attainment of the right results from usage of resources and organizational operations). Programme effectiveness is the extent to which programme objectives or intended consequences are achieved, where unintended negative effects occur, effectiveness must be judged on the balance of positive and negative consequences.

\section{Literature Review}

In the public sector, functions revolve around planning, budgeting, approval implementation and monitoring, controlling, recording transactions, accounting, auditing and reporting. After approving the budget, funds are 
released to Government ministries, departments, other agencies and parastatals to carry out specific functions approved in the budget. Funds are expended on the acquisition of goods and services. Infrastructures are repaired, renovated or new ones constructed and salaries are paid. Contractors are engaged in the execution of a significant number of the services. Government establishes rules, regulations and guidelines for the smooth operation of these functions.

The term value for money audit is a new entrant in public sector auditing literature, though the various aspects of the concept have been relatively observed in the process of accountability in the public sector. Johnson (1996: 72) noted that the concept is currently the subject of much discussion in the public sector, some taking the view that it presents a new concept aimed at checkmating the public office holders.

As public sector officers became more conscious of the need to ascertain the actual utilization of resources, the concept of value for money started to emerge. Ene (2000:10) indicated that value for money involves the appraisal of pursuit of the economy's efficiency and effectiveness in utilization of organizational resources.

In Nigeria, the concept became very pronounced because of the economic depression experienced since the 1980s. Government's emphasis shifted from expenditure control towards value for money as the need for effective utilization of economic resources became imminent (Ene, 2000:10). However, Okwoli (2004:80) stated that the concept of value for money audit has not gained the required level of recognition in Nigeria, though it lies within the jurisdiction of internal control, which is a management device for effective operation of the organization.

He further stated that the auditor should confirm that there is adequate accounting and financial system in operation. That the form and content of the accounts rendered confirm with statutory and treasury requirements. That the figures have been properly stated, that funds have been applied to the services and for the services intended, payments and receipts are in accordance with status and financial regulations.

Adeniyi (2004:210) gave the following as the objectives of value for money audit: Investigate a system or activity in the organization, Judge whether the objectives of the system are being achieved, and if not, why not, Judge whether the resources of the organization are being efficiently utilized in achieving the objectives and Judge whether the system is being operated economically, or whether there is over spending.

i. $\quad$ 'Value for money' (VFM) is a term used to assess whether or not an organisation has obtained the maximum benefit from the goods and services it both acquires and provides, within the resources available to it.

Some elements may be subjective, difficult to measure, intangible and misunderstood. Judgement is therefore required when considering whether Value for Money has been satisfactorily achieved or not. It not only measures the cost of goods and services, but also takes account of the mix of quality, cost and resource use, fitness for purpose, timeliness, and convenience to judge whether or not, together, they constitute good value.

ii. He emphasized further that achieving Value for Money is also often described in terms of the 'three Es' economy, efficiency and effectiveness. The definition of the three Es approved by the Value for Money Committee is as follows:

- Economy - Careful use of resources to save expense, time or effort.

- Efficiency - Delivering the same level of service for less cost, time or effort.

- Effectiveness - Delivering a better service or getting a better return for the same amount of expense, time or effort.

The need to expand public sector auditing beyond the financial (regularity and legal) audit, otherwise described as certificate audit, is in line with modern development in public sector auditing and an increasing demand for public accountability and transparency by members of the public (the tax payers) and other stakeholders.

Besides, and very importantly the Government's white paper of Ayida's Report on the Civil Service Reforms added value for money audit to duties of the Auditor General. Okwoli (2004)

While financial audit is still very essential and important, it has been realized that value for money audits are the more comprehensive approach to conducting audit of public programmes, projects and activities and the reports therefrom are more beneficial to the managers of public resources and attract more interest from the members of the public accounts and other stakeholders. Besides, it is the best approach to report accountability and transparency in the management of public resources.

Nigerians expect good governance and accountability from Governments (Federal, State or Local) in return for the tax they pay. Value for money audit provides ample opportunity for satisfying this expectation. Once properly 
implemented, value for money audit will contribute tremendously to the advancement of discipline and accountability in the implementation of public programmes and projects. Managers will be obliged to demonstrate what results they achieved and disclose the cost of the results.

Under value for money audit, focus is on achievement of results. Auditors will have to answer some basic questions before commencing detailed audit. Such questions are: What is the mission of the organization under audit? What is the objective of the programme, project or activity under audit? What are the goals and how are they being measured? The answers to these questions cannot come easily. It requires constant and vigorous training to be able to answer them.

A public sector auditor conducting value for money audit painstakingly examines and assesses the performance of government officials executing programmes, project, or activity to determine whether they are achieved at a minimal cost. The primary objective is therefore to confirm that relevant results expected from the programmes, projects and activities are achieved economically and efficiently. The auditors accumulates evidences to confirm that those entrusted with public resources are utilizing them economically, effectively, and achieving stated objectives. Causes of uneconomical practices are established and reported to the management for corrective action.

To confirm that the functions are performed economically and efficiently, the auditor will consider whether the organization is complying with the significant laws, regulations, rules, circulars, and guidelines relevant to the particular functions. It will be appropriate to confirm whether the organization is following sound procurement practices in the acquisition of goods and services. Whether organization is acquiring the appropriate cost and properly protecting and maintaining them. The audit will confirm that the organization is complying with laws and regulations that will significantly affect the acquisition protection and use of the organization and there is in place adequate management control system for measuring, monitoring and reporting on the application of economy and efficiency.

In the light of the above, this paper therefore, provides a conceptual analysis on value for money audit as a Veritable Tool for Expenditure Management.

\section{The Dynamic Nature of Public Sector Audit}

Auditing in public sector has moved a further step beyond simply legal supervisory and control. It has oriented its activities towards the evolution of administrative management of the incoherent. It has therefore undergone fundamental changes by being increasingly concerned with matters of economy, efficiency and effectiveness and the evaluation of Government programme results. This is often termed "Value for money Audit". Others call it "Management Audit" while in some countries it is known as "Operational Auditing" or "Performance Auditing". No matter which name it takes, the main aim is to determine whether value has been received for money that Government has spent or to evaluate the extent to which statutory or other goals are being achieved and whether alternative methods of operation should be considered. Value for money Audit, therefore, encompasses the review of the three Es-economy, efficiency and effectiveness. Of these three, economy and efficiency can be regarded as two sides of the same coin, using a classic input-output function theory. Audit of economy looks at the problem from input side. It examines whether it would be possible to achieve the same output with a smaller input of resources. Efficiency audit perceives the problem from output side that is, whether it would be possible to achieve higher output with given limited input of resources Chandler (1985).

It has been emphasized by Chandler (1985) that in matters of economy and efficiency the auditor may, where appropriate, consider whether the entity.

- Is following sound procurement procedures;

- $\quad$ Adopts proper procedure to ensure that the needed types, quality and amount of items are available and are properly used and maintained;

- $\quad$ Avoids duplication of efforts by employees;

- $\quad$ Uses efficiency operating procedures.

- Avoids work that serves little or no purpose; future cost and its position on the Government's priority rating.

- Avoids Over Staffing. In order for the auditor to reach a clear conclusion on the input-output relation observed, comparison with some standard relation or previous situation is necessary. Simple measurement of this relationship at a particular level of activity is not enough to tell us whether what we have observed or measured is good or bad. On the other hand, effectiveness audit is designed to check whether the 
purpose of a programme or individual project has actually been activated. Effectiveness means achieving the programmed objectives or goals Chandler (1985).

The subjects of efficiency and effectiveness audit are as numerous as the number and kinds of public sector activities of the Federal/State/Local governments. In the field of regularity audit, the law and regulations are based on it, as well as established norms; in particular the financial record keeping comes to the aid of the auditor. Prior to 1997, there were no readily applicable standard for value for money audit in Nigeria. The standards have been developed taking into account, the aims of Government activities, the specific circumstances of the society and norms prevalent in the relevant sector of the economy at home and abroad.

Chapter two (2) of the Auditing Standard can be found on the effort of the public sector auditing institution to set durable standard on issues of economy, efficiency and effectiveness. The standards are approved by the Federal Government. However, it has to be remembered that assessment of efficiency of public enterprise produces a compound of picture of management and operations-fault in decision, lack of coordination in higher echelons of management, lack of adequate economic analysis. This may be occasioned by objective judgment and can hardly and unequivocally be defined.

In the case, among the countries, which are leading the movement towards operation auditing is United State of America (USA). This recent concept of the control oriented towards evaluating the management of public sector programme, projects and services beyond the traditional financial area and at the same time emphasizing, broadcasting the supervisory control of administrative systems. Israel's Legislation gives clear mandate to the office of the Auditor-General to carry out operational audit. For over twenty years Sweden has been called "Effectiveness Auditing" which is primarily concerned with economy, efficiency and effectiveness audit. Australia is also very well advanced in it. Other countries that have made enviable progress along same direction include Peru, Chile, Venezuela and Ecuado in Latin America.

It is my fervent hope that this paper will strengthen the best of its consumer in the accountability process by practicing public sector value for money auditing in Nigeria. Economy, efficiency and effectiveness audits hinge on the Government activities in which vast resources are expended. Theory suggest and practice proved that judicious reading of audit reports can significantly improve decision making in the areas of government programmes, projects and services.

\section{Public Morality}

The normative activity of public sector audit is based consciously on the principles of propriety or even morality. The audit institution either in Federal, State or Local government tends to be highly and constantly aware of the president's or governor's duty to maintain, at all times, a high degree of justice, equity and fairness in dealing with citizenry. They also tend to populate high standards for judging such dealings. In particular, they take a jaundiced view of the expediency or shortage of resources used, to excuse improper acts or lack of consideration towards citizens.

The normal day-to-day behaviour of public servants are regulated by the laws and other written codes of behaviour / conditions of service. Serious offences such as theft, misuse of public funds and gross abuse of authority are regulated by the criminal codes and adequate base exists for dealing with them. Civil Service Rules and similar regulations deal with lesser offences through disciplinary procedures. But there are broad grounds of administrative behavior and discretion where decision are taken and implemented which can be questionable in terms of propriety and morality not covered by any law or rule. It is therefore the duty of the Audit Institutions to suggest ways to reduce the opportunities for making improper decisions. It is their duty to scrutinize improper decisions and in the process establish new norms of behaviour for the prevention of improper decisions in the future.

\section{Accountability and transparency process should not be stalled.}

Public Sector Audit, has thus, been defined by Chandler (1985) as the comparison of the reality of public administration (planning, implementation, and control) to norms, in order to induce corrections of shortcomings, effect improvements in managing and accounting for Government activities (programmes, projects and services).

Generally, auditing of the public sector activities is aimed at prevention of mistakes, shortcomings and misdeeds in the public administration (current phase audit). There are more specific effects of prevention. The institution and the probability that it can one day scrutinize some administrative action, prevents some gross abuses by those in authority and is instrumental in deterring the misapplication of funds. This implied fear will contribute to the willingness of public servants to act in compliance with discretion in an objective and reasonable way resulting in spending public funds carefully, judiciously and prudently. 
The above underscores the need for audit organization to have access to the auditing standards. The comprehensive nature of auditing carried out in accordance with objectives, the scope of work to be undertaken and the reporting requirements. Chandler (1985) maintains that the audit organization has responsibility for ensuring that:

- $\quad$ The audit is conducted by personnel who collectively have necessary skills.

- Independence is maintained.

- Applicable standards are followed in planning and conducing audits and reporting results.

- $\quad$ The organization has appreciable internal quality control system in place, and

- The organization undergoes external quality control review.

\section{Educational Role of Public Sector Audit}

In some establishments, little or nothing is known about accountability especially where there are political appointees from outside the system and who are uniformed. Such office holders unwittingly think that Government fund allocated for projects is to be spent according to their personal whims and caprices. The preventive role, therefore becomes necessary at the outset, before the misdeed is done, by drawing proper attention to the existing rules of the game. Current phase auditing is often necessary to monitor compliance. Organization of seminars and workshops helps in stemming the tide of mismanagement and misappropriation of public funds.

In some cases, the preventive role is not played by the audit organization alone. This is amplified below through examination of four stages of administrative process at which pre-audit can be carried out:

- The Planning Phase/Budgetary Stage: The office of Budget and planning with the data available examines the feasibility of a project, its ramifications in terms of future costs and its position on the Government's priority rating.

- The Release of Funds Phase: Once the budget has been approved by the Chief Executive, the release warrants can only be issued on the approval of the Chief Executive and after a thorough scrutiny of the request by the office of budget and planning as to priority allocation and validity of the request.

- Contractual Phase: The terms of agreement and mode and timing of payment and work done should be properly checked.

- Disbursement Phase: All relevant attestation documents must be scrutinized very carefully and the project supervision must have taken place with proper certificate of attestation as to work done and the value of such work. Since internal audit unit is an instrument of management control his scrutinization falls under the unit's responsibility. The Office of Accountant General will examine the relevant attestation document (payment voucher) to ensure that the voucher is flawless' before payment is authorized.

The primary objective of the contractual and disbursement phase is to ensure that the expenditure:

- $\quad$ Conforms to the purpose expressed in ambit of vote;

- $\quad$ Is within the amount granted in the approved estimates;

- $\quad$ Is covered by specific authority example, warrant;

- $\quad$ Is supported by valid vouchers showing proof of performance and evidence of payment to correct payee.

- $\quad$ Has come in the course of payment during the year.

\section{Reformation Role}

It is expected that the Audit institutions should achieve a measure of reforms in public administration. Suggestion on Budgeting, Governmental, Accounting, Internal Audit, Monitoring of project are potent areas for the Audit Institutions to tackle. If as a result of changed circumstances, for example, shortages of funds, lack of skilled manpower, changes in needs, it is impracticable or necessary to provide services stipulated by law, the Audit Institution is in the best position to suggest the necessary reforms to adjust outmoded plans to present reality. The Audit Institution should suggest the elimination of what is superfluous and discarding of dead woods no matter whose ox is gored. Auditors who have the clout can question bad policies. A follow up action is essential to ensure that the ascribed roles to the institution are performed with success.

The reputations of Public Sector Audit Institution are based on the personal and professional qualities of the Auditor-General and his staff. Such qualities include dedication, honesty, integrity, hard work, modesty, objectivity, and capacity to understand perspective. Insight and vision critics are of the view that, the practice whereby staff of the office of the Auditor-General are recruited by the Civil Service Commission which is subject to scrutiny of the 
Auditor-General is not the best approach. The absolute independence of the Audit Institution should be ensured if recruitment of staff is insulated from Civil Service Commission. Some critical observers also opine that most of the staff of the public sector audit are not qualified and knowledgeable as they had only on the job training based on regularity audit. They went on that this creates a personal impairment and so inhibits such staff from meaningfully playing the role of the Audit Institution in furtherance of accountability process. If auditors will come to grips with the reform engendered by value for money audit, they need sophisticated training. It is recognized that the then Federal Military Government in appreciation of the need for capacity building promulgated Decree Number 80 of 1990 which stipulated that $10 \%$ of Minister's personnel cost should be set aside in the budget and used for training programmes. This if implemented will reduce manpower problem. But good plans are marred at the altar of execution. In order to adequately and efficiently cover the audit of economy, efficiency and effectiveness not only accountants need be engaged by Audit Institutions but also other quality staff with varied qualifications in Engineering, System Analysis, Law, and Social Sciences should be called in. A combination of these without loss of professional pride will result in effective scrutiny of the public sector expenditure management in a dynamic economy. It will foster accountability and transparent process.

\section{Criteria Used in Value for Money Audit}

Criteria, according to Ene, (2000) (a)) are the yardsticks against which auditors assess actual performance. They are objective benchmarks that help auditors decide whether something is acceptable or whether it should be identified as a deficiency. They may be either quantitative or qualitative and are usually process-oriented, such as best practices or generally accepted norms. In other words, criteria are reasonable standards against which management practices, controls and reporting system can be assessed. They are used to judge the degree to which an audited organization conforms to expectations that have been explicitly articulated and sanctioned. Auditing cannot be done without audit criteria.

In value for money audit, criteria are defined as reasonable and attainable standards of performance and control against which the adequacy of the system and practices, and the extent of economy, efficiency, and effectiveness of operation, can be assessed in the particular circumstance of the audited organization. Value for money audits do utilize general audit criteria where relevant, but whenever necessary, relevant adjustments are made, sub-criteria are created and further specific tailor-made criteria are fashioned to provide audit assurance, address the auditors concerned and capture the requirements of the particular value for money audit exercise (Ene 2000 (a)).

The following are some value for money audit criteria presented by Ene, (2000 (a)):

\section{Planning and Acquiring of Capital Assets}

To control the planning of major capital projects, and acquisition, management should:

- $\quad$ Clearly define and communicate responsibility and accountability:- support request for funds with accurate and complete documentation;

- $\quad$ Base final approval on full information;

- $\quad$ Properly control project implementation, and review completed project.

\section{- $\quad$ Sub - Criteria}

(i) To arrive at an opinion that:

The need was justified

The technical requirements were appropriately specified

Available options were considered

The acquisition process was suitably managed

Custody and control of assets are provided for.

(ii) To assess performance against individual sub-criteria, example, to determine whether the acquisition process was suitably managed:

- $\quad$ Consider bid solicitation

- $\quad$ Access contractor selection

- $\quad$ Evaluate contract administration

- $\quad$ Analyse project controls and work - in - progress payment policy 


\section{Materials Management}

The following materials management criteria are associated with life cycle stages of material: needs definition, requirements definition, acquisition, in-service and disposal.

- The need for service should be well-defined and related to approved programme objectives.

- The requirements for material should be defined in such a way that the material required will enable the user to meet the need for a given service in an economical and efficient manner.

- Material should be acquired with due regard for economy at the time and in the quantity and quality required.

- Inventory control, storage and distribution should be economical and efficient.

- Equipment should be properly utilized.

- Repair and maintenance should be economical and efficient.

- Procedure should be in place to ensure adequate security and custody of material.

- Procedures should be in place to ensure that material is not misused.

- Disposal should yield maximum net benefit to the Government

\section{Procedures for Effectiveness:}

To measure and report the effectiveness of programs procedures should be in place which:

- Specify programme objectives and effects as precisely as possible.

- Identify programme objectives and effects that can be measured

- Reflect the state of the art and are cost-justified

- Report the result of effectiveness measurement

- Employ evaluations to increase programme effectiveness

\section{Efficiency:}

To help control the efficiency of work done, performance measurement systems should:

- $\quad$ Use relevant and accurate measures of performance.

- $\quad$ Compare performance to a standard.

- $\quad$ Tailor reports to management needs.

- $\quad$ Use performance data to achieve productivity improvement.

- $\quad$ Keep productivity measures and report correctly.

\section{Payroll Costs Management:}

To achieve value for money in staff training, managers should:

- Clearly define and communicate responsibilities for staff training

- Identify staff training needs

- Plan staff training activities and control their implementation

- Evaluate staff training activities

\section{The Procedures of Value for Money Audit}

According to Ene, (2000 (b)) the process of conducting value for money audit in Government accounting System is divided into three phases.

Planning the Audit: This means determine audit scope, timing, objectives, criteria, methodology to be used, and resources required to ensure that the audit covers the most important organizational activities, system and controls.

Execution Phase: This involves collecting, testing and analyzing evidence that is appropriate in quality and quantity based on audit objectives, criteria and methodology developed in the Planning Phase.

This Phase is carried out by applying audit techniques for:

- Testing and evaluating controls. 
- Identifying efforts variance from criteria and considering main causes and

- Developing conclusions and recommendations.

Reporting Phase: This is the final phase in the audit process. It involves communicating the results of audits to management, and reporting to the legislature or Board of directors.

These three Phases-Planning, Execution and Reporting are usually carried out in the sequence indicated, that is, the output or result of the work of one phase will form the basis for planning the work of the following phase. The three phases, and various steps within them, are part of a total process which in practice is highly inter-related. For example, although understanding the entity is a step in the planning phase, actual understanding of the entity improves throughout the entire audit. Moreover in the planning phase, attention must be given to reporting considerations. It must be pointed out that considerable attention and time should be devoted to the planning phase because of its importance to the success of the overall audit.

\section{Management Controls and Value for Money Audit}

A number of major audit management controls should be established and strictly applied in order to ensure that audits are conducted in accordance with acceptable office standards and also in the most efficient manner possible. In consonance with this during each step in the Audit Process a specified control is exercised as follows:

Overview Stage (Planning Phase): A review of the survey plan should establish that it reflects a good understanding of the entity and, based on that understanding of the entity, an adequate scope for the survey has been developed, suitable staff identified, and efficient time budgets prepared.

Preparing the Survey Report (Planning Phase): The Survey report and outline audit plan (specifying the audit scope, the proposed audit criteria and the resources needed to conduct execution phase once revealed and approved serve as the authority to begin the execution phase of the audit.

Preparing Detailed Audit Plan and Audit Programme (Planning Phase): These documents (which specify the audit objectives, the steps to be performed and the nature and extend of the audit work required) serve as basis for project leaders to begin, assign and carry out work in specific audit areas.

Conducting Tests and Obtaining Audit Evidence (Execution Phase): A review of the evidence obtained (in terms of its relevance to audit objective and degree of its persuasiveness and conclusiveness) will permit project leaders to assess its sufficiency.

Finalizing Reports (Reporting Phase): A review of detailed and summary reports will establish the fairness of finding and the reasonableness of improvements recommended.

\section{Application of Value for Money Audit}

Value for Money Audit is conducted both in the public sector and in the private sector, it is usually known as management or performance audit.

The public sector environment undoubtedly is different from the private sector environment. It is because of this that the value for money auditor must be thoroughly acquainted with that environment if he intends to be successful:

- $\quad$ Government institutions, establishment, organizations, or units do not have profit as their primary objective at their inception. They are expected to render needed services to citizens at reasonable costs.

- $\quad$ Government and its institutions are owned collectively by citizens who make contributions through direct and indirect taxes for their upkeep, subsistence and growth. Ownership is not usually evidenced by share certificates or coupons, which may be traded.

- Stakeholders in Government and its institutions do not always get in proportion to their financial contribution benefits that can be regarded as getting value for their money.

- $\quad$ Therefore, government and its institutions or other non-profit organizations exists because the community or society supporting them want them to continue to operate without minding that they do not get reciprocal benefit from such institutions.

- $\quad$ It is believed that Governments, institutions of Government and non-profit organization hardly die because of lack of patronage. These days, this belief may not be founded as many governments or institutions are almost bankrupt and therefore are in danger of total collapse. 
- $\quad$ For survival, all the three tiers of Government and the institutions of Government must utilize their scarce resources economically, efficiently in order to achieve their objectives. Effective control measures must be in place if their goals are to be achieved-in both the short and long term.

In Nigeria, Governments (Federal, States and Local Government Authorities) have experienced so much dynamic growth in the last ten years that the capital expenditure on State and Local Government Authorities have more than doubled. Federal Government employs a very large network of railways, roads, air transport, and marine transport systems. To do all these, it budgets yearly billions of naira, which we hardly get value for.

If the citizens of Nigeria must get value for money spent by the three tiers of Government, there must be:

- $\quad$ Sound financial management system that includes appropriate budgeting systems, sound accounting and reporting systems, decision oriented auditing systems and honest managers of our resources at all levels of Government.

- $\quad$ Distinction between pure Government operations and those profit-oriented operations of Government that must subject themselves to measures of performance of the private sector.

- $\quad$ Distinction between quasi-private sector organization for which cost-benefit measures must be applied in order to determine whether they are adhering to the practice of economy and effectiveness in their operations. For this class of organizations or institutions additional non-qualitative financial measures of performance are to be developed and used for their assessment. Governments are therefore to be audited by the legislative auditor with respect to:

- $\quad$ Financial Management and Control

- $\quad$ Reporting on performance

- $\quad$ Attesting to the financial statements and authority of transaction

- $\quad$ Management Controls

- $\quad$ Economy, efficiency and effectiveness.

The auditor's report should of course, contain findings on Government performance in these areas. All the operations of the public sector are dictated, governed and circumscribed by laws and regulations. They are regulated by law but not by profit motive or drive for excellence.

In order to move these organizations towards the achievement of their objectives, administrative as well as bureaucratic controls are established. However, these controls mean very little since Governments can also get their funds through taxation or by printing of new moneys. Consequently, government and its institutions continue to operate ineffectively, uneconomically and inefficiently.

\section{Obstacles to the Conduct of Value for Money Audit}

There are certain obstacles that impede the effective conduct and timely completion of value for money audit. Okwoli (2004) classified them into both External obstacle and Internal obstacles.

\section{External Obstacles}

According to Okwoli (2004) there are certain established and recognized management practices which facilitate the conduct of value for money audit. Where these practices are non-existent or even where existent are not spelt out in sufficient details, the auditor will certainly experience serious handicap in successfully executing a meaningful value for money audit.

\section{Ways Out}

It is therefore incumbent on the auditors to establish that these generally accepted management practices are in operation in the organization under audit. Where the contrary is the case, the auditor should not hesitate to report accordingly. Of primary importance is the set-up of the organization understanding of the particular programme, project or activity. The organizational set up must be such that the authority is well defined and identified. Responsibilities should be very clear to every member of the organization to the extent that individual roles are clearly known without ambiguity. Where authority is delegated, it must be accompanied with adequate power. The situation in the organization must be such that it will be very clear to any interested party on who is in charge and handle what responsibility. This is to enable accountability to be clearly placed. The advantage is that if any shoddy work or inefficiency is noticed, the responsible individual will easily be identified. The absence of these well-defined 
roles of members in an organization, department or unit dealing with a particular programme, project, or activity under audit, will certainly constitute an obstacle to a value for money auditor.

The objectives of the particular programme, project, or activity undertaken by the organization or agency must be clearly stated and document made available to the auditor. Within the objectives, targets, must be set with their completion time frames stated. In additions, there should be adequate allocation of funds and other resources to meet timely settlement of completion certificate and overall completion of the project. This helps to compare the completion time of the project with the agreed time scale and will contribute in identifying the bottlenecks militating against time completion deadlines. Where information on the objectives and their targets including completion time schedules are not available to the auditor, the value for money audit will be very difficult. This development will compel the auditor to search for the objectives and their targets.

All applicable laws, regulations, circulars, rules and internal guidelines governing the execution of particular programmes, projects and activities must be strictly complied with. Compliance includes following closely laid down internal guidelines and procedures for the implementation of the project. This step by step approach should be recognized, documented and followed. The auditor should be in possession of this information failing which is frustrating.

Effective control measures must be established and maintained. This is to ensure that the appropriate objectives, targets, specifications and standards are maintained. The controls should ensure that the finances are safeguarded, assets protected and loss or pilfering minimized. Part of this control system must be effectively of internal audit headed by a management staff with adequate competent staff and working tools. Where internal audit is non-existent or ineffective, the auditor will be constrained to spend more resources on mere regularity audit, which will vitiate the conduct of value for money audit.

There should be effective internal monitoring system in operation besides the internal audit unit. A monitoring team comprising relevant personnel with the technical-known-how in the particular project should be in existence within the organization. Their primary role will be to ensure that all the provisions in the agreement, specifications, and other technical details relating to the project are adhered to, that objectives are followed, target are being met and that the project cost is effective and within the budget. The team which among others must include an accountant who must pay constant site inspection visit to the project to make an on the spot assessment. It should be mandatory for the team to always issue inspection report to management on each completed tour. The report must be comprehensive and indicate variance observed between expected achievements and actual performance. Causes of variances must be highlighted and appropriate recommendations for improvements made to management. Where the need arises, an external monitoring team could be contracted to complement the function of the internal team. It will be appropriate to design standard information on the inspection tours. The responsibility of the value for money auditor will be to authenticate the veracity of these reports but where they do not exist the job of the auditor will be in serious stress.

Finally, there should be a system for staff development within the organization or agency undertaking projects so that the knowledge of the staff involved in the execution of these assignments should be updated constantly to bring in line with modern developments in their career. In addition, there should be provision for the hiring of consultants where necessary.

\section{Internal Obstacles}

In the views of Okwoli (2004) value for money audit is an onerous responsibility for the auditor. The audit report resulting there from must be factual, objective, and convincing. Therefore, the efficiency of the audit organization must be relatively high. The atmosphere and environment of the audit, the staff is expected to be conversant with the demands of value for money audit and must be adequately sensitized and properly oriented. Value for money audit is a team effort and the team should collectively possess the skill and expertise for the effective prosecution of the audit. If the audit team lacks the necessary professional competence and skill for the audit, it will constitute an obstacle.

\section{Ways Out}

The management of the audit office must establish strategic plans for the overall coverage of their statutory responsibilities allocating appropriate time, men and material resources for value for money audit. Value for money audit demands a lot of resources which are in short supply, value for money audit must not be handicapped. If the office does not establish the overall strategic plan, they may not be adequately positioned for value for money audit assignments. There must be effective quality control system in the office. This is to ensure that the reports are of high 
quality. There must be close supervision of subordinates for focus and compliance with audit work plans. The absence of these facilities will be an obstacle for effective value for money audit exercise.

The office of the Auditor-General must endeavour to be aware of the major contracts by Government and to demand for the early submission of the relevant contract agreements. The bulk of the value for money audit assignments is on capital projects, many of which are handled by contractors. Therefore the contract agreements are very crucial to value for money audit. It will constitute a serious obstacle to value for money audit if auditors are denied copies of agreements or where they are not received in time.

The office of the Auditor-General could face very serious obstacles on the conduct of value for money audit where it suffers from acute shortage of skilled manpower, lack of sufficient equipment/working tools and poor funding. Value for money audit involves extensive touring to project sites. Therefore the audit office must be equipped with touring vehicles. Adequate funding is very important for the Auditor-General to afford him necessary working tools including computers, photocopiers, and writing sheets for the timely rendition and transmission of audit report. Sufficient training programme should be scheduled for the staff of the Auditor-General in order to continue to update their knowledge, skill and attitude.

There is the need to update the Audit Law to give prominent emphasis on value for money audit. This will reflect Government's acceptance of value for money audit and clear any lingering doubt on the statutory coverage for value for money audit. This will equally accord the audit office a high leverage.

Anticipated risks could be an obstacle to the conduct of value for money audit. Value for money is usually a sensitive exercise. The reports attract a lot of attention of the Public Accounts Committee (PAC) and other stakeholders. Affected individuals of organizations may resort to threats, which can weaken the effort of the individual auditors or the audit office. On the other hand, the audit office for fear of stepping on powerful toes may decide against undertaking value for money audit or fail to report comprehensively on audit findings. Such self-inflicted obstacles should be avoided as much as possible.

\section{Summary and Conclusion}

Value for money audit which is a recent phenomenon in Nigeria is a useful tool of curtailing expenditure in the public service. Its main components are efficiency, effectiveness, and economy. It ensures that taxpayer's money is judiciously used for the purpose for which it is meant, thus providing the available goods and services for the benefits of the people.

This system of auditing is necessary because it expands the scope of auditing from regularity audit, to internal audit to other modern developments in auditing like certificate audit, management audit, thus ensuring public accountability and transparency by members of the public and other stakeholders. Value for money audit is a more comprehensive approach to conducting the audit of public programmes, projects, and activities than regularities audit/internal audit. It is concerned with results, performances of Government officials executing programmes, projects and courses of action so as to ensure accomplishment of goals and objectives.

Values for money audit are used in curtailing extravagant expenditure by determining the geniuness of transactions at the lowest possible cost.

For value for money audit to be successful, suitable criteria have to be used. Sources of audit criteria are determined by the auditor through a review of the nature of the programmes involved and the key operational characteristics of the management process.

Amongst the criteria sources are:

- Generally accepted accounting standards

- Public sector auditing standards

- Good management principles and practice

- Specials audit guides

- Law, policy statements or statements of ethical practice by professional associations.

- Pragmatism

- Innovations.

\section{Recommendation}

Suitable criteria are useful in curtailing extravagant expenditure because: 
- They provide useful benchmark for assessing management of financial, human and material resources, and for determining that value for money audit is being achieved.

- Provide a means for managers to develop or compare their own management procedures and

- Constitute a basis for senior managers to evaluate their systems and procedure. Value for money audit is therefore a useful tool for curtailing extravagant expenditure in the public service. Public sector organizations at the Federal, state and local g qw

- Overnment levels should therefore embrace the concepts of value for money audit and integrate it in their organizations. This is because a lot of cost saving and other advantages await them from such realization.

\section{References}

Adeniyi, A.A. (2004). Auditing and Investigations. El-Toda Ventures Ltd. Lagos.

Chandler, R.A. (1985). Value for Money Auditing: Its Potential and Its Problems. ACCA Students Newsletter, December.

Ene, E. (2000). Value for Money Audit in the Public Sector. ICAN Student Newsletter, December.

Johnson, I.E. (1996). Public Sector Accounting and Financial Control. Financial Training Nigeria, Lagos.

Nwosu, M.E. (2013). Principles of Accounting with Questions and Suggested Solutions. Petra Digital Press, Abuja.

Okwoli, A.A. (2004). Value for Money Auditing in the Nigeria Public Sector: Its Problems and Prospects in the Next Millennium. Go-go Int'1 Ltd. Jos.

Oshisami, K. (1991). Government Accounting and Financial Control. Pitman, Lagos.

Leff N. H. (1974). International Sourcing Strategy. Columbia Journal of World Business, 9(3), 71-79. 